\title{
Copper electrowinning in a moving-bed cell based on reactive electrodialysis ${ }^{(*)}$
}

\author{
L. Cifuentes* y P. Arriagada*
}

\begin{abstract}
A two-compartment lab-scale reactive electrodialysis (RED) cell with a moving particulate cathode has been used for copper electrowinning. The cathodic reaction was copper electrodeposition on a bed of copper particles forced to circulate inside a fixed cylindrical enclosure by the action of rotating paddles; the anodic reaction was ferrous to ferric ion oxidation on an anode made of static graphite bars. The anolyte (aqueous $\mathrm{FeSO}_{4}+\mathrm{H}_{2} \mathrm{SO}_{4}$ ) and catholyte (aqueous $\mathrm{CuSO}_{4}+\mathrm{H}_{2} \mathrm{SO}_{4}$ ) are kept separate by an anion membrane which prevents cation transport between the electrolytes. Experiments were carried out in order to characterize cell performance under various conditions. When operating with $40 \mathrm{~g} / \mathrm{L} \mathrm{Cu}(\mathrm{II}), \mathrm{I}=6 \mathrm{~A}, \mathrm{~T}=50^{\circ} \mathrm{C}, 40 \mathrm{rpm}$ paddle rotation and $990 \mathrm{~mL} / \mathrm{min}$ electrolyte recirculation flowrate, the specific energy consumption (SEC) for copper electrowinning was $2.25 \mathrm{kWh} / \mathrm{kg}$. An optimization of cell dimensions gave an improved SEC of $1.55 \mathrm{kWh} / \mathrm{kg}$ whereas a temperature increase from 50 to $56^{\circ} \mathrm{C}$ (without changing cell dimensions) produced a SEC of $1.50 \mathrm{kWh} / \mathrm{kg}$, which is $25 \%$ lower than normal values for conventional copper electrowinning cells. A comparison was drawn between the performance of this cell and a squirrel-cage cell previously developed by the authors.
\end{abstract}

\section{Electroobtención de cobre en una celda de lecho móvil basada en electrodiálisis reactiva}

Resumen

Palabras clave

\begin{abstract}
Una celda a escala laboratorio de electrodiálisis reactiva (EDR), de dos compartimientos con cátodo particulado móvil, se ha utilizado para electroobtener cobre. La reacción catódica fue la electrodeposición de cobre sobre un lecho de partículas de cobre que circulan dentro de un cilindro fijo por la acción de paletas rotatorias; la reacción anódica fue la oxidación de ión ferroso a ión férrico sobre un ánodo hecho de barras de grafito estáticas. El anolito $\left(\mathrm{FeSO}_{4}\right.$ $+\mathrm{H}_{2} \mathrm{SO}_{4}$ acuoso) y el catolito $\left(\mathrm{CuSO}_{4}+\mathrm{H}_{2} \mathrm{SO}_{4}\right.$ acuoso) se mantienen separados por una membrana aniónica que impide el transporte de cationes entre los electrólitos. Se efectuaron experimentos para caracterizar el funcionamiento de la celda bajo varias condiciones. $\mathrm{Al}$ operar con $40 \mathrm{~g} / \mathrm{l} \mathrm{Cu}$ (II), I = $6 \mathrm{~A}, \mathrm{~T}=50^{\circ} \mathrm{C}, 40 \mathrm{rpm}$ de rotación de paletas y un caudal de recirculación de $990 \mathrm{ml} / \mathrm{min}$, el consumo específico de energía (CEE) para la electroobtención de cobre fue de $2,25 \mathrm{kWh} / \mathrm{kg}$. Una optimización de las dimensiones de la celda produjo una mejora del CEE a 1,55 kWh/kg, mientras que un aumento de temperatura de 50 a $56^{\circ} \mathrm{C}$ (sin cambiar las dimensiones de la celda) produjo un CEE de $1,50 \mathrm{kWh} / \mathrm{kg}$, que es $25 \%$ menor que los valores convencionales para celdas de electroobtención de cobre. Se hizo una comparación entre el funcionamiento de esta celda y la de una celda tipo "jaula de ardilla" desarrollada anteriormente por los autores.
\end{abstract}

Electroobtención. Electrodiálisis reactiva. Ingeniería de reacciones. Membranas. Transferencia de masa. Electroquímica.

\section{INTRODUCTION}

Conventional copper electrowinning cells exhibit limitations (limited mass transfer rates, limited specific surface area of the cathodes, high specific energy consumption, environmental issues) which have led to the development of several alternative designs ${ }^{[1]}$ such as the fluidised bed cell[ $[2-6]$, the spouted bed cell[ ${ }^{[7-9]}$ and the squirrelcage cell ${ }^{[10]}$. These cells have been shown to produce reductions in energy requirements. Both the limitations of conventional cells and the development of new designs have recently been discussed ${ }^{[10}$ and 11]. 
Alternative cell designs include the use of membranes to separate catholyte from anolyte, alternative cathode geometries in order to increase the specific surface area of the cathode and alternative anodic reactions so as to replace water oxidation to gaseous oxygen ${ }^{[12]}$. In the latter case, it has been stressed that the nature of the anodic material is of paramount importance.

Despite the fact that membrane-based copper electrowinning cells have not yet been implemented in industrial production, they remain promising given: a) that some designs have produced considerable reductions (over $50 \%$ ) in specific energy consumption, and b) that the ferric compounds produced in the anolyte exhibit a far higher cost (6 to 10 times higher) than the ferrous compounds use as reactants. It is clear, however, that further work is required before the new designs are used in large-scale copper production.

The present work describes the experimental development of a new copper electrowinning cell design: a lab-scale moving-bed cell based on reactive electrodialysis. It also aims at comparing the performance of this cell with that of the previously tested squirrel-cage cell[ ${ }^{[10]}$.

In order to comply with the aforementioned objectives, a two-compartment moving-bed cell (one for cathode and catholyte and one for anode and anolyte) was developed. The catholyte compartment includes a fixed cylindrical enclosure inside which the particulate cathode is forced to circulate by mechanical means.

Both the moving-bed cell and the squirrel cage cell are based on circulating particulate cathodes but their cathode assemblies are different. Both cells exhibit advantages compared to conventional technology, e. g. increased mass transfer rates and increased specific surface area of the cathode, but they also exhibit limitations such as heterogeneous cathodization and physical discontinuity of the particulate bed.

\section{EXPERIMENTAL}

The moving-bed cell (MBC) is a type of reactive electrodialysis (RED) cell[10 and 11], as it uses an anion membrane to separate catholyte from anolyte in a current-driven process. The membrane prevents iron leakage from anolyte to catholyte and copper leakage in the opposite direction. It therefore prevents loss of cathodic current efficiency that would be caused by ferric to ferrous ion reduction in case the ferrous ion reached the cathode. A schematic of the cell is shown in figure 1 . Details of the cathode assembly are pictured in figures $2 \mathrm{a}$ ) and $2 \mathrm{~b}$ ).

The lab-scale cell was made of acrylic; the inner compartment dimensions were $80 \times 110 \times 135 \mathrm{~mm}^{3}$ for the cathodic compartment and $80 \times 80 \times 135 \mathrm{~mm}^{3}$ for the anodic compartment. The cathode and anode compartments were separated by an Ionac MA 3475 anion membrane. The latter was exposed to the electrolytes through an $80 \times 70 \mathrm{~mm}^{2}$ window cut in the adjacent acrylic walls of both compartments. To

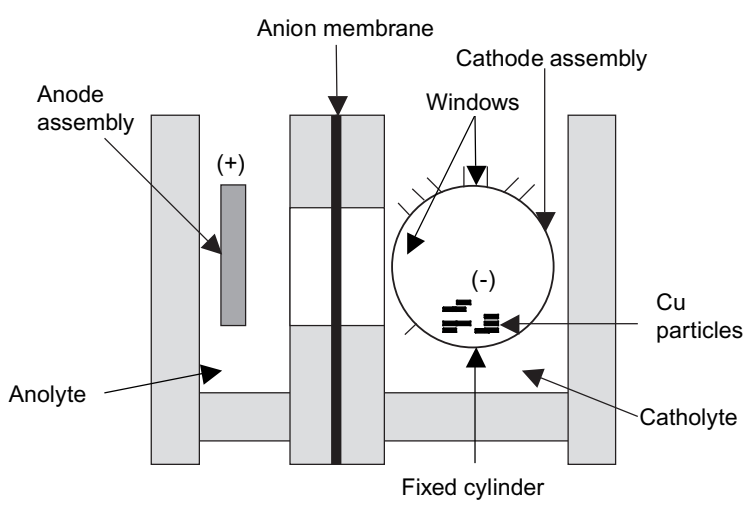

Figure 1. Schematic of moving-bed cell.

Figura. 1. Esquema de la celda de lecho móvil.
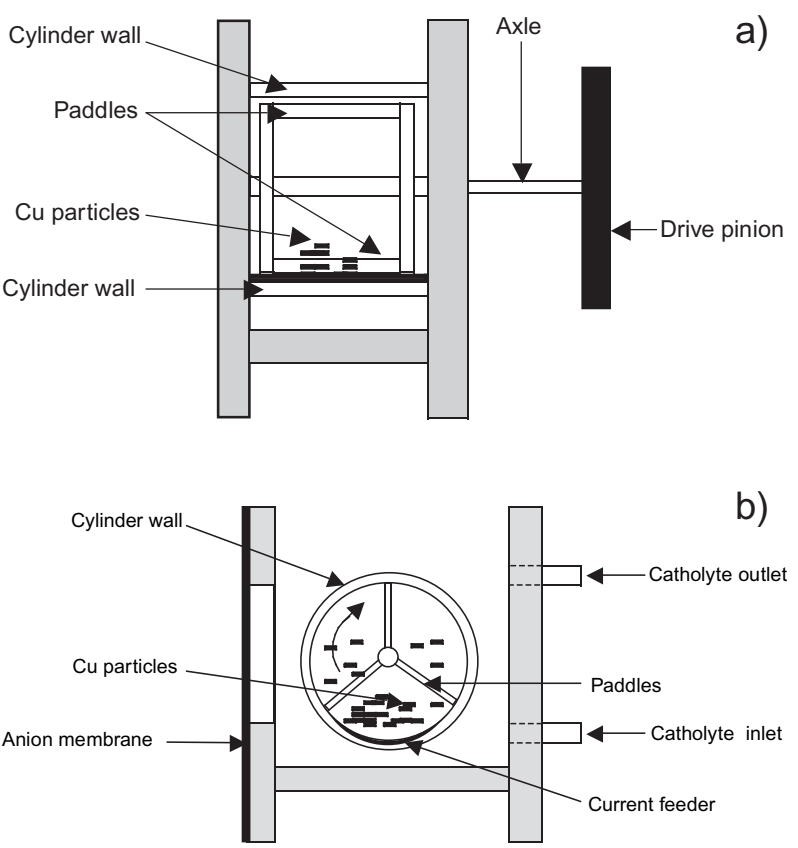

Figure 2. a) Front view of cathode assembly (view from the membrane). b) Side view of cathode assembly.

Figura 2. a) Vista frontal del cátodo (visto desde la membrana). b) Vista lateral del cátodo. 
avoid electrolyte leakage, $2 \mathrm{~mm}$ thick rubber seals are placed on both sides of the membrane. The cell was held together by 5 stainless steel bars bolted at both ends. Details of membrane properties and pretreatment have been given elsewhere ${ }^{[11 \text { and } 13]}$.

The composition of the catholyte was $40 \mathrm{~g} / \mathrm{l} \mathrm{Cu}$ (from cupric sulphate) and $190 \mathrm{~g} / \mathrm{l}$ sulphuric acid. The composition of the anolyte was $56 \mathrm{~g} / \mathrm{l} \mathrm{Fe}$ (from ferrous sulphate) and $190 \mathrm{~g} / \mathrm{l}$ sulphuric acid. Analytical grade chemicals were used throughout.

The moving-bed cathode was made of $200 \mathrm{~g}$ of copper particles ( $99.99 \%$ purity) with an apparent surface area of $364 \mathrm{~cm}^{2}$ and a specific surface area of $0.182 \mathrm{~m}^{2} / \mathrm{kg} \mathrm{Cu}$. The particles were copper wire segments shown in figure 3 (average dimensions: 7 $\mathrm{mm}$ length and $3 \mathrm{~mm}$ diameter). The cylindrical enclosure was made of polyamide; its length was 80 $\mathrm{mm}$ and its diameter was $80 \mathrm{~mm}$. A rotating arrangement made of three polyamide paddles (surface area $=70 \times 6 \mathrm{~mm}^{2}$, rotating speed $=40 \mathrm{rpm}$ ) forced the movement of the particulate bed inside the cylindrical enclosure. Four windows cut in the polyamide frame allowed circulation of the catholyte in and out of the fixed cylinder, as shown in figure 1. Dimensions were $50 \times 50 \mathrm{~mm}^{2}$ for the window facing the membrane and $70 \times 10 \mathrm{~mm}^{2}$ for the three windows placed on the upper side of the cylinder. In order to keep the copper particles inside the cylinder, the windows were covered with polyethylene net.

The anode was made of 31 graphite bars $(4.8 \mathrm{~mm}$ diameter and $150 \mathrm{~mm}$ ) of the same apparent surface area as the moving bed. The bars were placed vertically, partially immersed $(110 \mathrm{~mm}$ immersed

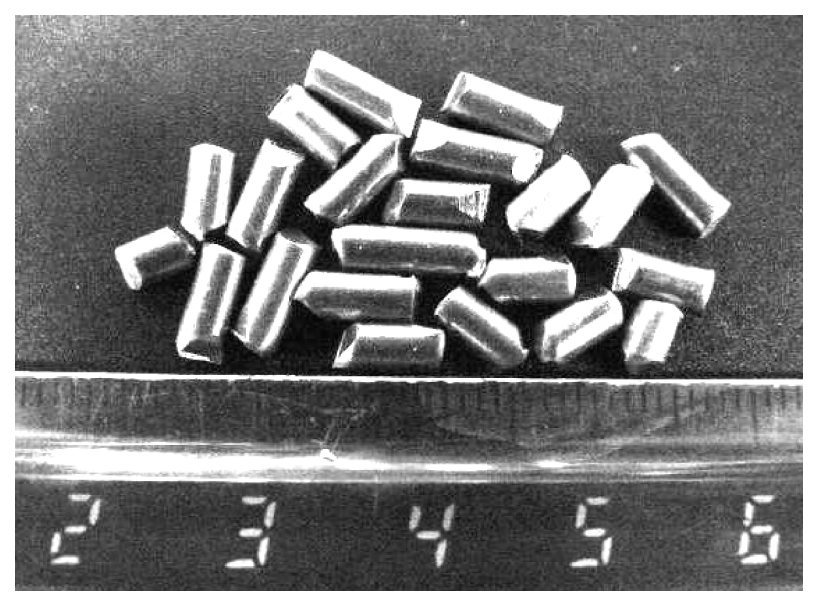

Figure 3. Copper particles which make up the moving bed. The scale unit is $\mathrm{cm}$.

Figura 3. Partículas de cobre que forman el lecho móvil. La unidad de la escala está en $\mathrm{cm}$. depth) and wired together with $0.5 \mathrm{~mm}$ copper wire in their exposed upper ends.

Electrolyte agitation was achieved by recirculation to two ad hoc $5 \mathrm{~L}$ tanks, one for the catholyte and one for the anolyte. For this purpose, inlet and outlet tubes ( $5 \mathrm{~mm}$ inner diameter) were fitted at the back of each compartment (Fig. 2 b)). The electrolyte flow was driven by Watson-Marlow $505 \mathrm{~S}$ peristaltic pumps. Current to drive the cell was provided by a 20 A, 30 V Idisa rectifier; it was fed to the bed by a copper plate $\left(70 \times 70 \mathrm{~mm}^{2}\right)$ placed on the lower inner surface of the cylinder.

The anode-cathode distance was as follows: anode-fixed cylinder surface: $45 \mathrm{~mm}$; anode-fixed cylinder axis: $85 \mathrm{~mm}$.

Two and three-hour copper electrodeposition runs were carried out at $27,36,50$ and $56^{\circ} \mathrm{C}$, catholyte and anolyte recirculation flowrates of 412 and 990 $\mathrm{cm}^{3} / \mathrm{min}$ and cell currents of 4 and 6 A. Additional agitation in the anolyte compartment was provided by a Stuart Scientific SS3 stirrer equipped with a $3 \mathrm{~cm}$-diameter impeller operating at $500 \mathrm{rpm}$. The operation conditions for the moving-bed cell runs are in table I. Current densities referenced to the apparent surface area of the membrane $\left(i_{m}\right)$ are also given.

A cell voltage vs. cell current density sweep was carried out in order to determine possible limitations on the applied cell current due to mass transport through the membrane. The cell current was applied by the previously mentioned rectifier. The initial current was $1 \mathrm{~A}$, which was applied during one minute in order to achieve cell voltage stabilization; subsequently, the cell current was increased by $1 \mathrm{~A}$ and, again, kept constant during one minute. This process was repeated up to a cell current of $27 \mathrm{~A}$, which was near the upper current limit for the rectifier used.

All electrode potentials are referenced to the standard hydrogen electrode (SHE).

\section{RESULTS AND DISCUSSION}

\subsection{Cell voltage vs. cell current density sweep}

The cell voltage vs. cell current density sweep is shown in figure 4 . A slight cell voltage decrease was detected at a cell current density of about 2,400 $\mathrm{A} / \mathrm{m}^{2}$, but the general trend was linear and no gas evolution was observed at either electrode during the whole experiment. This result demonstrates that the membrane poses no limitations to the passage of current up to a value of $2,700 \mathrm{~A} / \mathrm{m}^{2}$. Taking into 
Table I. Experimental conditions for moving-bed cell runs

Tabla I. Condiciones experimentales para la celda de lecho móvil

\begin{tabular}{lcccccccc}
\hline \multirow{2}{*}{ Conditions } & \multicolumn{8}{c}{ Experiment } \\
\cline { 2 - 9 } & $\mathbf{1}$ & $\mathbf{2}$ & $\mathbf{3}$ & $\mathbf{4}$ & $\mathbf{5}$ & $\mathbf{6}$ & $\mathbf{7}$ & $\mathbf{8}$ \\
\hline $\mathrm{l}, \mathrm{A}$ & 6 & 6 & 6 & 6 & 6 & $\mathbf{4}$ & 6 & 6 \\
time, h & 3 & 2 & 2 & 2.5 & 3 & 3 & 3 & 3 \\
$\mathrm{i}_{\mathrm{m}, \mathrm{A} / \mathrm{m}^{2}}$ & 1,071 & 1,071 & 1,071 & 1,071 & 1,071 & 714 & 1,071 & 1,071 \\
$50 \mathrm{~T}{ }^{\circ} \mathrm{C}$ & 50 & 36 & 27 & 56 & 50 & 50 & 50 & 50 \\
{$[\mathrm{Cu}], \mathrm{g} / \mathrm{l}$} & 40 & 40 & 40 & 40 & 10 & 40 & 40 & 40 \\
$\mathrm{Q}^{(1)}, \mathrm{cm}^{3} / \mathrm{min}$ & 990 & 990 & 990 & 990 & 990 & 990 & 412 & 990 \\
Paddles rotation, rpm & 40 & 40 & 40 & 40 & 40 & 40 & 40 & 70 \\
\hline
\end{tabular}

(1) Values of $Q$ are for both catholyte and anolyte.

Anolyte agitation $=500 \mathrm{rpm}$ in all cases.

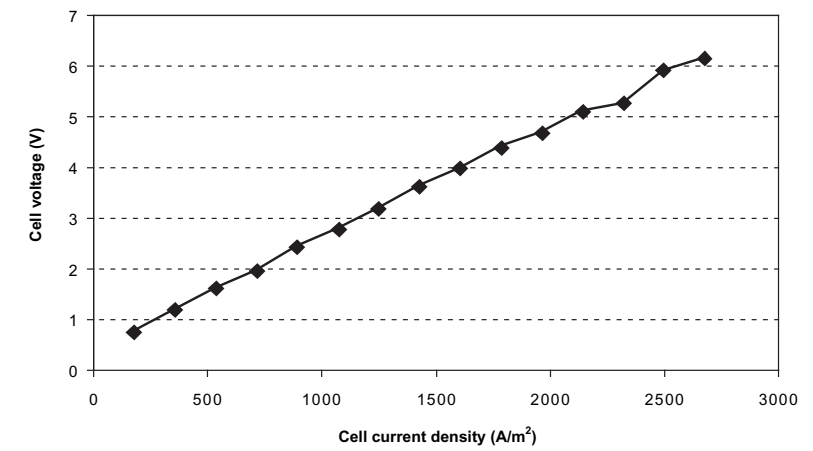

Figure 4. Plot of cell voltage against cell current density.

Figura 4. Gráfico de la tensión de celda en función de la densidad de corriente de celda. account that in the experiments reported in the present work the highest applied cell current density was $1071 \mathrm{~A} / \mathrm{m}^{2}$, it can be concluded that current limitations did not affect cell performance.

\subsection{Cell operation parameters}

Results for the experiments defined in table I are given in table II. Average cell voltage, cathodic current efficiency, specific energy consumption and deposit type are given for each experimental run.

For the studied cases, the kinetics was given by expressions derived from Fick's law and from high-field approximations to the Butler-Volmer equation. For cathodic and anodic reactions, the reaction rates are:

Table II. Experimental results for moving-bed cell runs

Tabla II. Resultados experimentales para la celda de lecho móvil

\begin{tabular}{lcccccccc}
\hline \multirow{1}{*}{ Parameter } & \multicolumn{8}{c}{ Experiment } \\
\cline { 2 - 9 } & $\mathbf{1}$ & $\mathbf{2}$ & $\mathbf{3}$ & $\mathbf{4}$ & $\mathbf{5}$ & $\mathbf{6}$ & $\mathbf{7}$ & $\mathbf{8}$ \\
\hline $\mathrm{V}_{\text {cell }}^{(1)}, \mathrm{V}$ & 2.55 & 2.77 & 3.50 & 1.72 & 2.96 & 2.12 & 2.58 & 2.80 \\
$\mathrm{CCE}^{(2)}, \%$ & 96.7 & 65.9 & 58.7 & 97.1 & 61.2 & 97.1 & 89.9 & 79.1 \\
$\mathrm{SEC}^{(3)}, \mathrm{kWh} / \mathrm{kg}$ & 2.25 & 3.54 & 5.03 & 1.50 & 4.08 & 1.84 & 2.42 & 2.99 \\
Deposit type & cont $^{(4)}$ & cont & cont & cont & powd(5) & cont & cont & cont \\
\hline
\end{tabular}

(1) Average; (2) CCE = cathodic current efficiency; ${ }^{(3)} \mathrm{SEC}=$ specific energy consumption; ${ }^{(4)} \mathrm{cont}=$ continuous Cu deposit; ${ }^{(5)}$ powd = powdery Cu deposit. 


$$
\begin{aligned}
& \left|i_{c}\right|=\frac{i_{0 c}{ }^{b}\left|i_{L c}\right|}{i_{0 c}^{b}+\left|i_{L c}\right| \exp \left(\frac{\alpha_{c} F}{G T} \eta_{c}\right)} \\
& i_{a}=\frac{i_{0 a}{ }^{b} i_{L a}}{i_{0 a}{ }^{b}+i_{L a} \exp \left(\frac{-\alpha_{a} F}{G T} \eta_{a}\right)}
\end{aligned}
$$

The cell voltage is given by

$$
V_{\text {cell }}=\Delta E_{e}+\eta_{a}+\left|\eta_{c}\right|+I\left(R_{a}+R_{c}+R_{m}\right)+L
$$

the energy required to drive the cell is

$$
W=V_{c e l l} l t
$$

and the specific energy consumption is

$$
S E C=\frac{W}{m_{d e p}}
$$

The electrical resistance of catholyte and anolyte is given by

$$
R=\frac{1}{\kappa} \frac{d}{A}
$$

where, $\mathrm{d}$ is the distance travelled by ions in the corresponding electrolytes (e. g., between membrane and electrode).

Table II shows that all three operation parameters varied within fairly wide ranges for the conditions studied: $1.72-3.50 \mathrm{~V}$ for the cell voltage, 58.7 - 97.1 $\%$ for the cathodic current efficiency and $1.50-5.03$ $\mathrm{kWh} / \mathrm{kg}$ for the specific energy consumption.

\subsection{Cell voltage calculation}

The cell voltage and its components (equation 3 ) were calculated for the base case (experiment 1). Conditions are shown in table I.

The equilibrium potentials were calculated by Nernst's equation. For the cathodic reaction, $\mathrm{E}_{\mathrm{e}}$ varied only slightly during the experimental run and may be estimated at $0.40 \mathrm{~V}$. On the other hand, the equilibrium potential for the anodic reaction varied between 0.66 and $0.77 \mathrm{~V}$ during the same run, giving an average value of $0.72 \mathrm{~V}$. The difference between the equilibrium potentials $\left(\Delta \mathrm{E}_{\mathrm{e}}\right)$ was then $0.32 \mathrm{~V}$.
The overpotentials of the cathodic and anodic reactions were calculated by equations (1) and (2), with data obtained from previously published work for RED cells ${ }^{[10}$ and 14$]$, giving $0.2 \mathrm{~V}$ for the anodic overpotential and $0.05 \mathrm{~V}$ for the cathodic overpotential.

Using equation (6) and data from Cifuentes et al. ${ }^{[10]}$, calculated IR drops in catholyte and anolyte were determined as 0.80 and $0.56 \mathrm{~V}$ respectively.

The IR drop in the membrane was calculated as $0.32 \mathrm{~V}$ using data taken from Cifuentes et al. ${ }^{[13]}$.

Finally, the L term in equation (3) refers to IR drops at electrical contacts in the circuit, mainly at the current feeder-electrode interfaces. Resistance measurements gave an overall value of $\mathrm{L}=0.26 \mathrm{~V}$.

The sum of the calculated components (Eq. (3)) gave $2.51 \mathrm{~V}$ for the base case, which compares well with the measured value of $2.55 \mathrm{~V}$, a relative error of about $1.5 \%$.

\subsection{Effect of cell current}

Results in table II (experiments 1 and 6) indicate that, at constant temperature, the cell voltage increased with cell current; this is to be expected from a process where both reactions (cathodic and anodic) take place under mixed control. Further, the effect of current on the cell voltage is clearly expressed by equation (3): all terms on the right hand side of this equation (except for the first one) increase with increasing current.

\subsection{Effect of temperature}

Results for experiments 1-4 indicate that both the cell voltage and the specific energy consumption decrease with increasing temperature: a $29{ }^{\circ} \mathrm{C}$ temperature increase caused a $50 \%$ decrease in $\mathrm{V}_{\text {cell }}$ and a $70 \%$ decrease in SEC. This is the result of a solution viscosity drop which leads to an increase in the mobility and diffusivity of ions, thus enhancing mass transfer phenomena and increasing the values of the limiting current densities (Eqs.. (1) and (2)). The latter change causes a decrease in the cathodic and anodic overpotentials (Eqs. (1) - (3)). On the other hand, it is well known that charge transfer phenomena are also accelerated by increasing temperature and Cifuentes et al. ${ }^{[13]}$ have quantified these effects for RED cells which use the $\mathrm{Cu}^{+2}+2 \mathrm{e} \rightarrow \mathrm{Cu}^{0}$ and $\mathrm{Fe}^{2+} \rightarrow \mathrm{Fe}^{3+}+$ e reactions.

The best (lowest) value for specific energy consumption $(1.50 \mathrm{kWh} / \mathrm{kg})$ was achieved for experiment 4 , carried out at $56^{\circ} \mathrm{C}$, the highest studied temperature. This confirms the importance of temperature on the overall performance of the $\mathrm{MBC}$. 


\subsection{Effect of recirculation flowrate}

Results from experiments 1 and 7 showed that a catholyte and anolyte recirculation flowrate decrease from 990 to $412 \mathrm{~cm}^{3} / \mathrm{min}$ caused a slight increase in both the cell voltage (from 2.55 to $2.58 \mathrm{~V}$ ) and the specific energy consumption (from 2.25 to 2.42 $\mathrm{kWh} / \mathrm{kg}$ ). This could be explained by the effect of agitation on the mass transfer rate. In the case of the catholyte, this means that a lower degree of agitation outside the fixed cylinder caused a diminished mass transport rate towards the inner volume of the cylinder.

\subsection{Effect of copper concentration}

Results from experiments 1 and 5 indicate that a lower initial cupric ion concentration $(10 \mathrm{~g} / \mathrm{l}$ compared to $40 \mathrm{~g} / \mathrm{l}$ for the base case) caused an increase in cell voltage (from 2.55 to $2.96 \mathrm{~V}$ ), a fall in cathodic current efficiency (from 96.7 to $61.2 \%$ ) and an increase in the specific energy consumption (from 2.25 to $4.08 \mathrm{kWh} / \mathrm{kg}$ ). The increase in cell voltage was due: a) to a decrease in the electrical conductivity of the catholyte which, in turn, was caused by a drop in cupric ion concentration; the result was an increase in the catholyte's IR drop; b) to a decrease in the limiting current density of the cathodic reaction, which increased the overpotential of the electrodeposition reaction.

The drop in cathodic current efficiency can be explained by the experimental observation of hydrogen evolution at the cathode surface during experiment 5. In this case, part of the cathodic current was used by the parasitic $2 \mathrm{H}^{+}+2 \mathrm{e} \rightarrow \mathrm{H}_{2}$ reaction. The specific energy consumption increase was caused by the decrease in cathodic current efficiency (lower deposited copper mass per unit time).

The copper electrodeposits, which were continuous and dendritic in all other experiments, exhibited a fine powdery morphology when the cupric ion concentration was reduced to $10 \mathrm{~g} / \mathrm{l}$. The physical quality of copper electrodeposits produced on non-conventional cathodes has been discussed elsewhere ${ }^{[15-17]}$.

\subsection{Variation of the cell voltage with ti- me of operation}

Figure 5 shows the variation of cell voltage with time of operation for all eight experiments defined in table I. The highest cell voltage at all times corresponded to experiment 3 , carried out at $27^{\circ} \mathrm{C}$ (the lowest temperature) whereas the lowest cell voltage

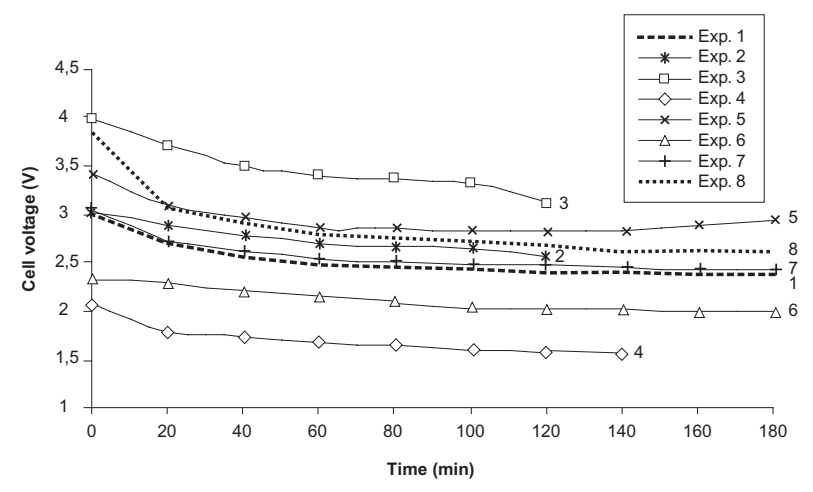

Figure 5. Cell voltage against time for experiments described in table I.

Figura 5. Tensión de celda en función del tiempo para los experimentos descritos en la tabla I.

at all times corresponded to experiment 4 , carried out at $56^{\circ} \mathrm{C}$ (the highest temperature). These results patently demonstrate the strong influence of temperature on the cell voltage and, therefore, on the energy required to drive the cell (Eq. (4)).

The second lowest cell voltage was exhibited by experiment 6 , which was conducted at the lowest cell current density. This result was to be expected in view of equations (1) and (2), valid for mixed control kinetics.

The curves for experiments 1,7 and 8 are similar despite the fact that their corresponding experiments differ in the catholyte recirculation flowrate and the paddles rotation rate. This points to the relatively reduced influence of these variables on the cell voltage.

In seven cases $(1-4,6-8)$, the cell voltage decreased with time by $10-15 \%$ in a two to three hour period, although most of the drop occurred during the first sixty min. In cases 1 and 6-8 the cell voltage tended to a constant value after about $120 \mathrm{~min}$. In one case (experiment 5) the cell voltage first decreased and then, after about $140 \mathrm{~min}$, it started to increase.

These curves show a complex pattern previously discussed by Cifuentes et al. ${ }^{[10]}$ : the cell voltage behaviour in RED cells depends on five factors: a) an initial cell voltage decrease due to ion absorption by the membrane, which increases its conductivity; b) a steady cell voltage increase as copper ions are depleted from the catholyte by electrodeposition, with a resulting conductivity drop; c) a steady cell voltage decrease due to the increase in the $\left[\mathrm{Fe}^{3+}\right] /\left[\mathrm{Fe}^{2+}\right]$ ratio as ferrous ion oxidizes to ferric ion at the anode, leading to a decrease in the value of the $\mathrm{DE}_{\mathrm{e}}$ term; d) a steady cell voltage increase due to ferrous ion depletion in the anolyte, which decreases both the limiting current density and the exchange 
current density for ferrous ion oxidation, leading to an increase in the anodic overpotential.

Results show that, for the present work, the cell voltage decreasing factors were more important than those which tend to increase the voltage, but a longer cell operation time could have reversed this behaviour. The only curve that showed a cell voltage increase after 140 minutes was the one corresponding to experiment 5 , which exhibited the lowest cupric ion concentration $(10 \mathrm{~g} / \mathrm{l})$. This fact enhanced the effect of factor b) above.

\subsection{Cathodic current efficiency and specific energy consumption}

The main effects on cathodic current efficiency (CCE) and specific energy consumption (SEC) were those of temperature and cupric ion concentration. An increase in any of these variables led to a CCE increase and to a SEC decrease, i.e., a two-fold improvement in cell performance. The reasons for these effects were discussed in the previous sections.

Some experiments showed a decrease in the cathodic current efficiency of the MBC. There are three main causes for this phenomenon:

a) The first cause was mentioned in section 3.7, i. e. the observed hydrogen evolution from the bed in experiment 5 . This was caused by a low concentration of cupric ion in solution, which increased the relative importance of $\mathrm{H}^{+}$reduction to gaseous hydrogen at the particulate cathode.

b) The second likely cause was poor recirculation of the catholyte in and out of the fixed cylinder, which could be an additional source of cupric ion depletion from the catholyte leading to hydrogen evolution. Given the fact that the latter was only observed in experiment 5 suggests that in other cases the evolution took place at a lower rate. The fact that there are only four windows (i. e. a limited window surface area) on the cylinder surface, and none of them facing the catholyte inlet could explain the poor recirculation.

c) The third likely cause was unwanted copper deposition on the feeder plate inside the fixed cylinder. The structure of the cell made it very difficult to measure the weight of the feeder plate after experiments, but a very low amount of deposition was observed in some cases, in contrast with the much greater unwanted deposition that took place on current feeders in several experiments carried out with the squirrel cage cell[10].

These three causes are likely to have contributed, in varying proportions, to the decrease in the measured cathodic current efficiency in experiments 2, 3, 5 and 8 .

\subsection{Comparison with the squirrel cage cell}

A comparison between the performances of the MBC and a squirrel-cage cell[ ${ }^{[10]}$ is shown in table III. The squirrel-cage cell exhibits a cathode assembly in the shape of a rotating cylinder whose axis is perpendicular to the membrane. The cylinder rotation causes the movement of the particulate bed inside the cage. On the other hand, the MBC exhibits a cathode assembly made up of a fixed cylinder whose axis is parallel to the membrane. As explained above, bed movement is achieved in this case by rotating paddles inside the fixed cylindrical enclosure.

In table IV, the particle type and movement and the values of the cell voltage, cathodic current efficiency and specific energy consumption are presented for the squirrel-cage cell operating at 1,000 $\mathrm{A} / \mathrm{m}^{2}, 50^{\circ} \mathrm{C}$ and $40 \mathrm{~g} / \mathrm{l} \mathrm{Cu}$, and for the moving bed cell operating at $1,071 \mathrm{~A} / \mathrm{m}^{2}, 50^{\circ} \mathrm{C}$ and $40 \mathrm{~g} / \mathrm{l} \mathrm{Cu}$. The main difference between the conditions is the slightly higher $(7 \%)$ current density for the MBC. Despite the fact that both cells produce the same cathodic current efficiency, the squirrel-cage cell shows better

Table III. Calculated values for the components of the cell voltage (in V)

Tabla III. Valores calculados para los componentes de la tensión de celda (en V)

\begin{tabular}{ccccccccc}
\hline$\Delta \mathrm{E}_{\mathrm{e}}$ & $\boldsymbol{\eta}_{\mathrm{a}}$ & $\boldsymbol{\eta}_{\mathrm{c}} \mid$ & $\mathrm{IR}_{\mathrm{a}}$ & $\mathbf{I R}_{\mathrm{c}}$ & $\mathrm{IR}_{\mathrm{m}}$ & $\mathbf{L}$ & $\mathbf{V}_{\text {cell, }}{ }^{(1)}$ & $\mathrm{V}_{\text {cell, } \mathrm{m}}{ }^{(2)}$ \\
\hline 0.32 & 0.20 & 0.05 & 0.56 & 0.80 & 0.32 & 0.26 & 2.51 & 2.55 \\
\hline
\end{tabular}

(1) Calculated; (2) Measured. 
Table IV. Comparison between the performances of the moving bed cell (MBC) and the squirrel cage cell (SQCG) ${ }^{(1)}$

Tabla IV. Comparación entre los funcionamientos de la celda de lecho móvil (CLM) y la celda jaula de ardilla (CJA)

\begin{tabular}{ccccc}
\hline Cell & Cathode & Cell voltage V & CCE \% & SEC kWh/kg Cu \\
\hline MBC & Cu particles $^{(2)}$ & 2.55 & 96.7 & 2.25 \\
SQCG & Cu granules $^{(3)}$ & 1.91 & 96.7 & 1.67 \\
\hline
\end{tabular}

(1) Conditions: MBC: $1,071 \mathrm{~A} / \mathrm{m}^{2}, 50^{\circ} \mathrm{C}, 40 \mathrm{~g} / \mathrm{Cu}$; SQCG: $1,000 \mathrm{~A} / \mathrm{m}^{2}, 50^{\circ} \mathrm{C}, 40 \mathrm{~g} / \mathrm{Cu}$.

(2) Moved by rotating paddles in a static cylindrical enclosure (40 rpm).

(3) Moved by rotation of the squirrel cage (30 rpm).

Table V. Cell voltage components (in V) for moving bed cell and squirrel-cage cell(1)

Tabla V. Componentes de la tensión de celda (en V) para la celda de lecho móvil y la celda jaula de ardilla

\begin{tabular}{cccccccccc}
\hline Cell & $\boldsymbol{\Delta} \mathbf{E}_{\mathbf{e}}$ & $\boldsymbol{\eta}_{\mathrm{a}}$ & $\left|\boldsymbol{\eta}_{\mathrm{c}}\right|$ & $\mathbf{I R}_{\mathrm{a}}$ & $\mathbf{I R}_{\mathrm{c}}$ & $\mathbb{R}_{\mathrm{m}}$ & $\mathbf{L}$ & $\mathbf{V}_{\text {cell, calc }}$ & $\mathbf{V}_{\text {cell, meas }}$ \\
\hline MBC & 0.32 & 0.20 & 0.05 & 0.56 & 0.80 & 0.32 & 0.26 & 2.51 & 2.55 \\
SQCG & 0.40 & 0.34 & 0.10 & 0.37 & 0.41 & 0.30 & 0.05 & 1.97 & 1.91 \\
\hline
\end{tabular}

(1) Conditions are the same as in table IV.

figures for cell voltage and specific energy consumption (about $25 \%$ better in both cases).

Table $\mathrm{V}$ shows values of various components of the cell voltage for both cells. A consideration of these values leads to the conclusion that the MBC provides better (lower) values for $\Delta \mathrm{E}_{\mathrm{e}}, \eta_{\mathrm{a}}$ and $\mid \eta_{\mathrm{c}}$, i. e., terms that do not depend on cell geometry, but it is disadvantaged by the higher values of the IR drops in both electrolytes (between 50 and $100 \%$ greater than the corresponding values for the squirrel-cage cell), i. e., terms that do depend on cell geometry.

The IR drop in the membrane is slightly lower (better) for the squirrel-cage cell due to its higher apparent membrane surface area compared to that of the MBC. According to equation (6), the higher the membrane surface area, the smaller the electrical resistance of the membrane.

In addition, the $\mathrm{L}$ term (other voltage losses) in equation (3) is also higher for the MBC than for the squirrel-cage cell. This is mostly due to a better contact arrangement between the feed-wires and the anode bars for the squirrel-cage cell. The same arrangement could be applied to the MBC thus causing a reduction of up to $0.2 \mathrm{~V}$ in the $\mathrm{L}$ term.

The conclusion is that, in the studied cell conditions, the squirrel cage design provides a better performance than the $\mathrm{MBC}$ design, caused by its smaller anode-cathode distance and more efficient electrical connections.

\subsection{Scale-up}

For the present work, scale-up experiments were not carried out. Among the components of the cell voltage (Eq. (3)), at constant electrolyte composition and temperature, the overpotentials of the anodic and cathodic reactions, as well as the ohmic drop across the membrane, depend on cell current density and local mass transport phenomena and are independent of the size of the reactor; the equilibrium potential difference also remains constant with cell size.

The variables which are direct functions of cell dimensions and would have to be taken into account in an eventual scale up are: a) the anode-membrane (AM) and cathode-membrane (CM) distances, which determine the IR drops in anolyte and catholyte; b) the height and width of the membrane, given that the membrane's electrical resistance is inversely proportional to the membrane surface area $\left(\mathrm{A}_{\mathrm{m}}\right.$, see Eq. (6)); c) the radius and axial length of the fixed cylinder, which would influence both the 
hydrodynamics and the particle dynamics in the particulate bed; these would, in turn, affect the mass transfer rate. For this reason, any scale-up of the cylinder dimensions could only be carried out experimentally.

Table VI shows the calculated effect of cell dimension changes on the cell voltage and the specific energy consumption. The membrane-cathode distance was not varied, as it is limited by the dimensions of the fixed cylinder. For the base case dimensions $\left(\mathrm{AM}=0.04 \mathrm{~m}, \mathrm{CM}=0.055 \mathrm{~m}, \mathrm{~A}_{\mathrm{m}}=\right.$ $0.0056 \mathrm{~m}^{2}$ ), the measured cell voltage was $2.55 \mathrm{~V}$ and the $\mathrm{SEC}$ was $2.25 \mathrm{kWh} / \mathrm{kg}$. If the AM distance were reduced to $0.028 \mathrm{~m}$ as in Case $1\left(\mathrm{~A}_{\mathrm{m}}\right.$ remaining constant), the calculated cell voltage would drop to $2.34 \mathrm{~V}$ and the specific energy consumption, to $2.07 \mathrm{kWh} / \mathrm{kg}$ (an $8 \%$ decrease in both cases). If AM

Table VI. Effect of cell dimensions ${ }^{(1)}$ on the cell voltage and the specific energy consumption

Tabla VI. Efecto de las dimensiones de la celda sobre la tensión de celda y el consumo específico de energía

\begin{tabular}{ccccc}
\hline Case & $\mathrm{d}_{\mathrm{a}-\mathrm{m}} \mathrm{m}$ & $\mathrm{A}_{\mathrm{m}} \mathrm{m}^{2}$ & $\mathrm{~V}_{\text {cell }}{ }^{(2)} \mathrm{V}$ & $\begin{array}{c}\mathrm{SEC} \\
\mathrm{kWh} / \mathrm{kg}\end{array}$ \\
\hline Base & 0.040 & 0.0056 & 2.55 & 2.25 \\
1 & 0.028 & 0.0056 & 2.34 & 2.07 \\
2 & 0.028 & 0.0091 & 1.76 & 1.55 \\
\hline
\end{tabular}

(1) The cathode-membrane distance was $0.055 \mathrm{~m}$ for all three cases. $\mathrm{d}_{\mathrm{a}-\mathrm{m}}=$ anode-membrane distance

$A_{m}=$ Apparent surface area of membrane

${ }^{(2)}$ For the base case, $V_{\text {cell }}$ was measured; for cases 1 and 2 , it was calculated. remained as in Case 1, but the membrane surface area increased to $0.0091 \mathrm{~m}^{2}$ (Case 2), the calculated cell voltage would decrease further to $1.76 \mathrm{~V}$ and the SEC would drop to $1.55 \mathrm{kWh} / \mathrm{kg}$ compared to the base case (a $31 \%$ decrease in both cases). This shows the importance of cell dimensions on the energy requirements to drive the cell (Eq. (4)).

\subsection{Comparison of volumetric produc- tion rates}

The volumetric production rate is given by

$$
V P R=\frac{m_{d e p}}{v t}
$$

A comparison of the VPR for 4 cell designs is given in table VII. For the base case (MBC1), the VPR value is $3.23 \mathrm{~kg} / \mathrm{h} \mathrm{m}^{3}$. For the same cell with optimized dimensions $(\mathrm{MBC} 2=$ Case 2, in table VI) the VPR increased to $3.70 \mathrm{~kg} / \mathrm{h} \mathrm{m}^{3}$ (a $15 \%$ improvement). For the squirrel-cage cell, the VPR is $5.88 \mathrm{~kg} / \mathrm{h} \mathrm{m}^{3}$, which confirms the advantages of this design, already discussed in section 3.10. When a conventional, full-sized copper electrowinning cell was brought into the picture, its VPR was the lowest of the four cases at $2.93 \mathrm{~kg} / \mathrm{h}$ $\mathrm{m}^{3}$. The VPR's of the optimized MBC and of the squirrel-cage cell were $26 \%$ and $100 \%$ higher respectively than that of the industrial cell. Further, some advantages of the potential technology are: i) the availability and low cost of ferrous sulphate in Northern Chile; ii) the high market value of ferric compounds which can be obtained from the spent anolyte. These considerations demonstrate the

Table VII. Comparison between the performances of the moving bed cell, the squirrel cage cell and a conventional copper electrowinning cell(1)

Tabla VII. Comparación entre los funcionamientos de la celda de lecho móvil, la celda jaula de ardilla y una celda convencional de electroobtención de cobre

\begin{tabular}{clcccc}
\hline Cell & \multicolumn{1}{c}{ Cathode } & $\mathrm{V}_{\text {cell }} \mathrm{V}$ & CCE $\%$ & SEC $\mathrm{kWh} / \mathrm{kg}$ & $\mathrm{VPR}^{(2)} \mathrm{kg} / \mathrm{h} \mathrm{m}^{3}$ \\
\hline MBC1 & Cu particles, moving & 2.55 & 96.7 & 2.25 & 3.23 \\
MBC2 & Cu particles, moving & 1.76 & 96.7 & 1.55 & 3.70 \\
SQCG & Cu particles, moving & 1.91 & 96.7 & 1.67 & 5.88 \\
CONV(3) & Cu sheet, static & 1.98 & 91.0 & 1.98 & 2.93 \\
\hline
\end{tabular}

$\mathrm{MBC}=$ moving bed cell; SQCG = squirrel cage cell; CONV = conventional copper electrowinning cell.

(1) Conditions: $\mathrm{MBC} 1: 1071 \mathrm{~A} / \mathrm{m}^{2}, 50^{\circ} \mathrm{C}, 40 \mathrm{~g} / \mathrm{L} \mathrm{Cu}$ (base dimensions, see Table 6); MBC2: $1071 \mathrm{~A} / \mathrm{m}^{2}, 50^{\circ} \mathrm{C}, 40 \mathrm{~g} / \mathrm{L} \mathrm{Cu}$ (Case 2 dimensions, see Table 6); SQCG: $1000 \mathrm{~A} / \mathrm{m}^{2}, 50^{\circ} \mathrm{C}, 40 \mathrm{~g} / \mathrm{L} \mathrm{Cu}$; CONV3: $280 \mathrm{~A} / \mathrm{m}^{2}, 49^{\circ} \mathrm{C}, 42 \mathrm{~g} / \mathrm{L} \mathrm{Cu}$.

(2) Volumetric production rate in $\mathrm{kg}$ Cu per hour per cubic meter of cell.

(3) Data from industrial Cu electrowinning plant. 
potential advantages of alternative cell designs that aim to overcome the limitations of conventional technology.

However, it is worth noting that, when comparing the performances of lab-scale cells with those of industrial cells, it should be taken into account that the latter operate with impurities in solution which are absent in the synthetic electrolytes used for research. For instance, in a conventional cell, iron in solution leads to the parasitic $\mathrm{Fe}^{3+}+\mathrm{e} \rightarrow \mathrm{Fe}^{2+}$ reaction at the cathode, which reduces the cathodic current efficiency to $92 \%$ or less. On the other hand, the cost of: a) anion membrane; b) energy used in spinning the reactor; c) copper particles making up the bed, should also be taken into account. Further work is required before a more realistic comparison between the new lab-scale designs and industrial cells can be carried out.

\section{CONCLUSIONS}

Results obtained in a lab-scale copper electrowinning cell with a moving bed cathode indicate that:

- The cell voltage increased with cell current, which is to be expected for an electrolytic process where both main reactions are under mixed control and there are voltage drops in catholyte, anolyte and membrane, all of which depend on cell current.

- The effect of temperature on cell performance is of paramount importance, as it affects all transport phenomena (mass and charge transfer). The cell voltage decreases with increasing temperature and this effect determines the energy requirements for the moving bed cell. The higher the temperature, the better the cell performance. A SEC value of $1.50 \mathrm{kWh} / \mathrm{kg}$ was obtained at $56^{\circ} \mathrm{C}$.

- A decrease in cupric ion concentration (from 40 to $10 \mathrm{~g} / \mathrm{l})$ resulted in an increased cell voltage (16 $\%)$, a fall in cathodic current efficiency (37\%) and an increase in specific energy consumption (81\%), all of which are deleterious to cell performance.

- Cell voltage against time curves confirmed that the main variables affecting the cell voltage were temperature and cell current. On the other hand, the least influential variables were the recirculation flowrate and the paddles rotation rate. In most cases, the cell voltage decreased by about $15 \%$ after 180 min cell operation.

- The main effects on the cathodic current efficiency and the specific energy consumption were those of temperature and cupric ion concentration. An increase in either of these

variables led to a CCE increase and to a SEC decrease, i. e., an improved cell performance.

- In spite of the good performance results for the moving bed cell, the squirrel-cage design exhibited better figures for cell voltage and SEC in similar operation conditions. This was due to a smaller anode-cathode distance and more efficient electrical connections for the second design.

- A calculated optimization of the MBC dimensions (a smaller anode-membrane distance and a greater apparent membrane surface area) led to a considerable fall (31\%) in cell voltage and specific energy consumption.

- A comparison of the volumetric production rates for four copper electrowinning cell designs showed that the MBC could potentially outperform a conventional industrial cell with or without optimization of the MBC dimensions. The fact that the squirrel-cage cell also exhibits a superior performance goes to show that alternative cells have considerable potential, although further work is required before they can be considered for large-scale industrial production.

\section{Notation}

A

d

$\mathrm{E}_{\mathrm{e}}$

F

G

$\mathrm{i}_{\mathrm{a}}$

$i_{c}$

$\mathrm{i}_{\mathrm{L}}, \mathrm{i}_{\mathrm{L}, \mathrm{a}}, \mathrm{i}_{\mathrm{L}, \mathrm{c}}$

$\mathrm{i}_{0}, \mathrm{i}_{0, \mathrm{a}}, \mathrm{i}_{0, \mathrm{c}}$

I

$\mathrm{L}$

$\mathrm{m}_{\text {dep }}$

$\mathrm{R}, \mathrm{R}_{\mathrm{a}}, \mathrm{R}_{\mathrm{c}}, \mathrm{R}_{\mathrm{m}}$

$\mathrm{t}$

$\mathrm{T}$

$\mathrm{v}$

$\mathrm{V}_{\text {cell }}$

VPR

W surface area perpendicular to ionic flux, $\mathrm{m}^{2}$

distance travelled by ions, $\mathrm{m}$ equilibrium potential, $\mathrm{V}$

Faraday's constant, $\mathrm{C} \mathrm{mol}^{-1}$

Gas constant, $\mathrm{J} \mathrm{mol}^{-1} \mathrm{~K}^{-1}$

current density for an anodic reaction, $\mathrm{A} \mathrm{m}^{-2}$

current density for a cathodic reaction, $\mathrm{A} \mathrm{m}^{-2}$

limiting current density, anodic and cathodic, $\mathrm{A} \mathrm{m}^{-2}$

exchange current density, anodic and cathodic, $\mathrm{A} \mathrm{m}^{-2}$

cell current, A

other potential losses, $\mathrm{V}$

deposited Cu mass, $\mathrm{kg}$

electrical resistance, anolyte, catholyte and membrane, $\Omega$

time of cell operation, $s$

temperature, $\mathrm{K}$

cell volume, $\mathrm{m}^{3}$

cell voltage, $\mathrm{V}$

volumetric production rate, $\mathrm{kg} \mathrm{h}^{-1}$ $\mathrm{m}^{-3}$

cell driving energy, J 


$$
\begin{aligned}
& \alpha, \alpha_{\mathrm{a}}, \alpha_{\mathrm{c}} \\
& \Delta \mathrm{E}_{\mathrm{e}} \\
& \eta, \eta_{\mathrm{a}}, \eta_{\mathrm{c}} \\
& \mathrm{k}
\end{aligned}
$$

charge transfer coefficient, anodic and cathodic

difference between $\mathrm{E}_{\mathrm{e}}$ values of anodic and cathodic reactions, $\mathrm{V}$ overpotential, anodic and cathodic, $\kappa$ electrical conductivity of electrolyte, $\Omega^{-1} \mathrm{~m}^{-1}$

\section{Acknowledgements}

This work was funded by the National Committee for Science and Technology (CONICYT, CHILE) via FONDECYT project No. 101 0138. Thanks are due to Gloria Crisóstomo for her help with the experimental work and to Rodrigo Ortiz for helpful discussions. Continued support from the Department of Mining Engineering, Universidad de Chile is gratefully acknowledged.

\section{REFERENCES}

[1] R. KAMMEL, Hydrometallurgical Process Fundamentals, New York, Plenum Press, Bautista, R. A. (Ed.), 1982, 617-648.

[2] M. FLEISCHMANN AND J.W. OLDFIELD, J. Electroanal. Chem. 29 (1971) 211-230.

[3] M. FLEISCHMANN AND J.W. OLDFIELD, J. Electroanal. Chem. 29 (1971) 231-246.
[4] D. HUTIN AND F. COEURET, J. Appl. Electrochem. 7 (1977) 463-471.

[5] F. GOODRIDGE AND C.VANCE, J. Electrochim. Acta 24 (1979) 1237-1242.

[6] F. MASTERSON, Metall. Trans. B 13 (1982) 3-13.

[7] K. SCOTT, J. Appl. Electrochem. 18 (1988) 504-510.

[8] V.D. STANKOVIC AND S. STANKOVIC, J. Appl. Electrochem. 21 (1991) 124-129.

[9] V. JIRICNY, A. ROY AND J.W. EVANS, Metall. Mater. Trans. B 33 (2002) 677-683.

[10] L. CIFUENTES, R. ORTIZ AND J. M. CASAS, Am. Inst. Chem. Eng. J. 51 (2005) 2273-2284.

[11] L. CIFUENTES, R. GLASNER AND J. M. CASAS, Chem. Eng. Sci. 59 (2004) 1087-1101.

[12] L. CIFUENTES AND R. GLASNER, Rev. Metal. Madrid 39 (2003) 260-267.

[13] L. CIFUENTES, C. MONDACA AND J. M. CASAS, Miner. Eng. 17 (2004) 803-809.

[14] L. CIFUENTES AND J. SIMPSON, Chem. Eng. Sci. 60 (2005) 4915-4923.

[15] L. CIFUENTES AND M. MELLA, Can. Metall. Q. 45 (2006) 9-16.

[16] L. CIFUENTES, M. MELLA AND G. CRISÓSTOMO, Miner. Eng. 19 (2006), 1385 1387.

[17] L. CIFUENTES, M. GRÁGEDA AND G. CRISÓSTOMO, Chem. Eng. Sci. 61 (2006), 36233631. 